\title{
On the Thorium Transfer from Lithosphere to Hydrosphere. In Connection with the Occurrence of Thorium in Sea Water
}

\author{
Shinnosuke HIGASHI
}

\begin{abstract}
A study was carried out to explain the transfer process of thorium from lithosphere to hydrosphere.

Thorium is contained in granites in two forms: the former is contained in mineral resistates and is hardly transportable into solution, and the latter is contained in so-called leachable material and is easily transportable into solution. The experiments indicated that leachable thorium could be leached from granite by dilute hydrochloric acid and carbonated water.

The discussion was made on the problem how thorium was brought into river water and sea water during the weathering.
\end{abstract}

\section{1. 粕 言}

筆者は既に岩石, 河水, 海水, 温泉水, 動物及 び植物体中に微量含まれるトリウムに対して，各 々適切な分析法の研究を行つて来たのであるが， その間特に興味を持つたのは，如何なる過程を経 て岩石中のトリウムが河水, 海水, 温泉水乃至は 動植物体中に含まれるに至るかの点であつた．そ の理由は次のよ5である.

トリウムは主として花菵岩の副成分鉱物である トリアン石, トール石, トロゴム石, モナズ石, ジルコン, チタン石, 燐灰石, 褐策石中に含まれ て存在しているのであるが1), 周知の如くこれら の鉱物は風化に対して強い抵抗性を示し2), 従つ て花崗岩自体が風化崩潰し, 雨水等により流出さ れる際にも，これらの含トリウム鉱物は分解され ず，河口や海岸に集積して所謂漂砂鉱床を形成す る特性を持つている.

* 1959 年 2 月 17 日受理

** 京都大学教盖部化学教室 Denpartment of Chemistry, School of General Studies, University of Kyoto.
従つて, このょうに風化に対して強い抵抗性を 持つ鉱物からトリウムが溶出し, 河水や海水に含 まれるに至ると考えること自体，大きな矛盾があ ると云はなければならない。

然るに近年, 花崗岩中に, そして花崗岩に限ら れるのであるが，風化過程に於て容易に溶出する 形のトリウムが存在することが判明した．即ち，

G.R. TILTON ${ }^{3)}$ は前カンブリア紀の花崗岩中に含 まれる鉛, ウラン, トリウムの分布に関する研究 に於て, ウラン, トリウム, 及び非放射性起源の 鉛の相当量が花崗岩中に不安定な結合状態で存在 することを発見し，このように不安定な状態で存 在するウラン, トリウム, 鉛は, 6 規定の塩酸で 処理することにより容易に花崗岩から溶出するこ とを認め, その溶出量は花崗岩中に含まれる該元 素全量の, ウランは $34 \%$ トリウムは $43 \%$, 鉛は 40\%程度であると報告した。

続いてH. BROWN ${ }^{4)}$ は花崗岩粉末を塩酸水中に 投大し, 溶出する諸元素量を測定した結果, 試料 によつてかなり溶出量に差があるにもかかわら 
ず, 溶出した各元素間の比は大体一定で, $\mathrm{CaO}$; $15 \sim 45 \%, \mathrm{Fe}_{2} \mathrm{O}_{3} ; 11 \sim 46 \%, \mathrm{Al}_{2} \mathrm{O}_{3} ; 20 \sim 30 \%$ の值を示し, 希土類元素及び放射性元素は, その 全含有量の $40 \%$ 以上に相当する量が溶出されると 報じた. 更に BROWN は各種花崗岩試料につい て測定を行い, 花崗岩中には塩酸処理により容易 に溶出する物質が存在することを認め, これに “leachable material” (可浸出性物質) と名付け た.

続いて E.E. PICCIOTTO ${ }^{5)}$ は巧妙なラジオオー トグラフ法によつて, 花崗岩中に存在する放射性 元素の一部は花崗岩副成分鉱物中に存在し, 他は 石英, 長石, 雲母等の結晶間隙に存在することを 観察し, BROWN の名付けた leachable material 中に含まれる放射性元素は, この結晶間吵に存在 するものであらうと推定した。

筆者はこの leachable material 中に含まれる トリウムに着目し, このトリウムが風化過程に於 て花崗岩から溶出するものであらうと考光, 自然 界に於て岩石を溶解する主因となつている雨水に 最も近い炭酸水で花崗岩を処理し, 期待量のトリ ウムが溶出されることを認め, 続いて各種風化段 階の異る花崗岩についてその中に含まれているト リウム量を分析し, 風化過程に於てトリウムが花 崗岩から逸散していることを検し，これらの結果 と, 既に測定した河水, 海水中のトリウム量とを 比較検討して, 花崗岩中のトリウムの溶出挙動の 解明を試みた。以下これについて報告したい。

\section{2. 実 験}

a）塩酸処理によつて溶出する花崗岩中のトリ ウム

花崗岩試料を 100 ×ッシ以下に粉砕し, 約 $3 \mathrm{~g}$ を科取し $30 \mathrm{ml}$ の 6 規定塩酸中に投入, 室温で覺 拌する. 所定時間後これに $70 \mathrm{~m} l$ の蒸溜水を加え て希釈し濾過する. この滤液にアンモニア水を加 えて微アルカリ性となし, 生じた水酸化物の沈澱 を濾別洗滌する. 試料岩石から溶出したトリウム は，この水酸化物の沈澱中に含有される. これに 塩酸を加えて溶解し, ウオターバス上で加温濃縮 し，この中に含まれる可溶性ケイ酸を不溶性にす
る. 不溶性ヶイ酸を滤別し, 得られた試料溶液に アンモニア水を加えて水酸化物の沈澱を作成さ せ，水洗滤別する．これに少量の硝酸を加えて水 酸化物を溶解させ, 続いて約 $10 \mathrm{~g}$ の硝酸アンモ二 ウム（固体）を加え全量が $10 〜 20 \mathrm{ml}$ になるよう に蒸溜水を加える. これを $\mathrm{pH} 0.65$ に調節し， 分液濾斗でこれとほぼ同量のサイクロヘキサノン を用いて二回抽出を繰返す.」トリウムを抱含した サイクロヘキサノンを合してこれに約 $10 \mathrm{ml}$ の蒸 溜水を加え, トリウムを水層へ逆抽出し, この操 作を更に約 $5 \mathrm{~m} l$ の新蒸溜水で完結させる.

しかる後有機試薬 o-arsonophenyl-azo-chromothropic acid') による比色分析法でトリウムの定 量を行ふ.

花崗岩中に含まれる全トリウム量の測定は，筆 者の先に報告したトリウムの微量分析法第 3 報7) の方法に従つた.

上述の処理法により, 6 規定塩酸によつて花崗 岩から溶出されたトリウム量と, 塩酸処理時間と の関係を第 1 図に示す。使用した花崗岩試料は, 京都市左京区瓜生山産のトリウム含有量 $20.6 \gamma / \mathrm{g}$ 及び大文字山産のトリウム含有量 $20.1 \gamma / g$ の二種 であつた。

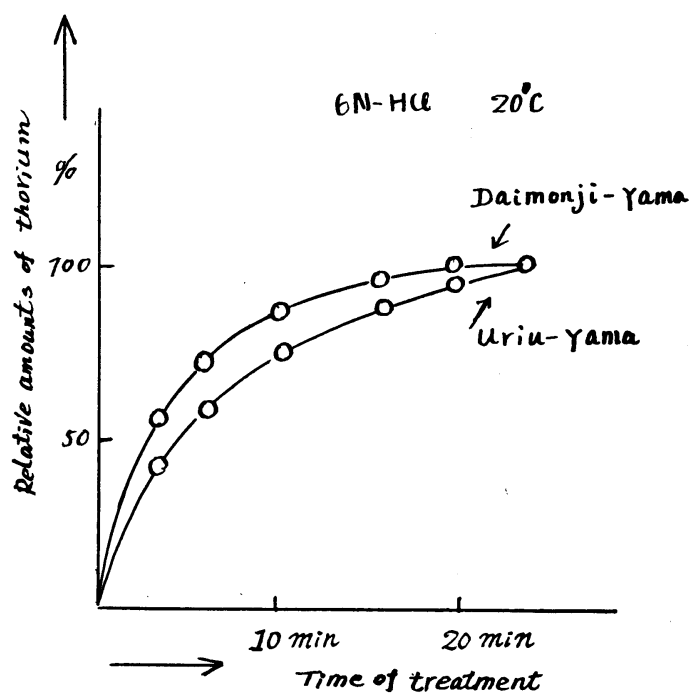

Fig. 1. The relation between the amounts of extraction of thorium from granite and the time of leaching. 
第 1 区にみられるよ $5 に ， 6$ 規定塩酸処理によ り, トリウムは比較的短時間で試料岩石から溶出 され，25分を経た後の溶出量はほとんど一定值を 示す. 又この処理を 12 時間行つた後の溶出トリウ ム量は, 瓜生山試料, $7.8 \mathrm{\gamma} / \mathrm{g}$, 大文字山試料, $8.3 \gamma / \mathrm{g}$ であつた. この值をもつて 6 規定塩酸に より溶出し得るトリウムの全量と規定し第 1 図を 作成した. 6 規定塩酸で溶出したトリウム量と,該 試料花崗岩中の全トリウム量との比は夫々 $37.8 \%$ (瓜生山), $41.0 \%$ (大文字山) であり, 前述 TILTON 等の結果とほぼ一致している.

次に試料花崗岩の粉砕程度と, 6 規定塩酸処理 により溶出するトリウム量との関係を調べてみ た.

試料花崗岩を粉砕し, タイラー標準篩の 100 メ ッシ, 60 メッシ, 35 メッシ， 20 メッシを用いて， 100 メッシを通過部， 60 メツシを通過し 100 メ ツシを通過しない部分（以下 100〜60 と略記す る), 60〜35, 35〜20 各部分に篩い分け, 各々を 6 規定塩酸の 12 時間処理を行つて溶出したトリ ウム量を測定し，この值とタイラーのメツシ目と

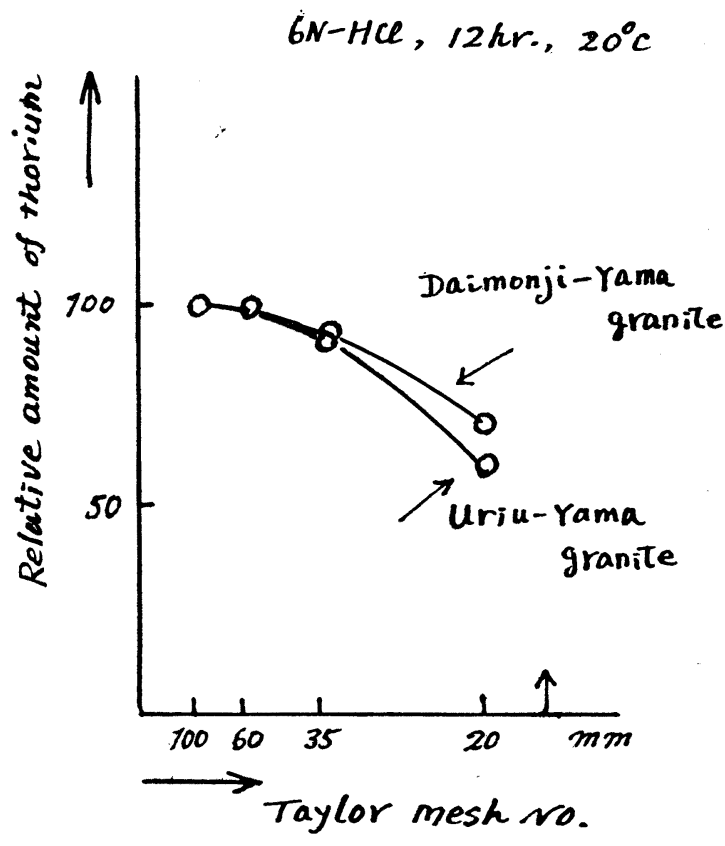

Fig. 2. The relation between the amounts of extraction of thorium from granite and degree of powdering.
比較したのが第 2 図である.

第 2 図の縦軸は 100 メッシを通過した試料から 溶出したトリウム量を $100 \%$ として，これに対し て各粉砕度の異る試料から溶出したトリウム量の 相対值をとり，横軸は篩の目の大きさを $\mathrm{mm}$ で比 較してある。

第 2 図でみられるように，60メッシ以上の粉砕 度の試料から溶出されたトリウム量は殆んど変ら ない。このことから推定して，比較的荒い粉砕度 でも充分トリウムは溶出されることが判明した。

b) 希塩酸及び炭酸水処理により花崗岩から溶 出するトリウム

6 規定塩酸処理で溶出する花崗岩中のトリウム は, 希塩酸及び炭酸水でも溶出するものか否かを 検した，処理法は次のようである.

瓜生山花崗岩を 100 ×ッシ以下に粉砕し, 所定 の $\mathrm{pH}$ に調節した希塩酸 $100 \mathrm{~m} l$ に対し岩石粉末 $10 \mathrm{~g}$ の割合で投大, ポリエチレン製瓶中に 保存

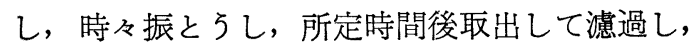
この滤液中に含まれるトリウム量を前記方法で測 定した。処理液の酸性が弱い場合は溶出されるト リウム量も少くなるので，この様な場合は試料岩 石粉末を $200 \sim 300 \mathrm{~g}$ 取り，これを 2 3l の処理 液を用いて，水酸化アルミニウム共沈法でトリウ 厶を捕集し測定した. 又溶出処理中, 溶出液の $\mathrm{pH}$ 值に変動の認められる場合, 例えば $\mathrm{pH}=3$ の希 塩酸で溶出を開始すると，24 時間後に処理液の $\mathrm{pH}$ 值は 3.8 となり, 又, $\mathrm{pH}=4$ で処理を開始する と, 2 時間後に $\mathrm{pH}$ 值はに 5.5 変ることが認めら

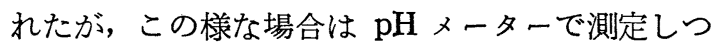
つ適時酸の補充を行つて初期の $\mathrm{pH}$ 值を保ち, 適 時酸の補充を行つて初期の $\mathrm{pH}$ 值を保ち, 溶出を 続行した.

希塩酸及び炭酸水処理により溶出したトリウム 量と, 溶出時間との関係を第 1 表に示す.

第 1 表の結果を更に明瞭にする目的で, 第 3 図 に於て処理液の酸性度と溶出されたトリウム量と の関係を，又第 4 図に於て酸性度と溶出速度との 関係を図示した。

第 3 図にみられるように, 溶出されたトリウム 量の対数と, 溶出液の $\mathrm{pH}$ 值の間に近似的な直線 
Table 1. The amounts of extraction of thorium $(\gamma)$ from granite $(g)$ with dilute hydrochloric acid and carbonated water. $(\mathrm{pH}=5.5)$ Uriu-Yama granite. Temp. $18-23^{\circ} \mathrm{C}$.

Time of extraction (Day)

\begin{tabular}{|c|c|c|c|c|c|c|}
\hline \multirow{3}{*}{ 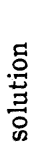 } & & 1 & 3 & 10 & 30 & 100 \\
\hline & 1 & 3.8 & 5.0 & 4.4 & 7.1 & 7.0 \\
\hline & 2 & 1.3 & 1.7 & 2.1 & 3.0 & 3.6 \\
\hline 茨 & 3 & 0.40 & 0.52 & 0.68 & 0.90 & 1. 15 \\
\hline \multirow{2}{*}{ 䍃 } & 4 & 0.12 & 0.16 & 0.21 & 0.27 & 0.34 \\
\hline & 5.5 & $1.6 \%$ & $2.4 ※$ & $3.0 \%$ & $3.8 \%$ & 4.6 \\
\hline
\end{tabular}

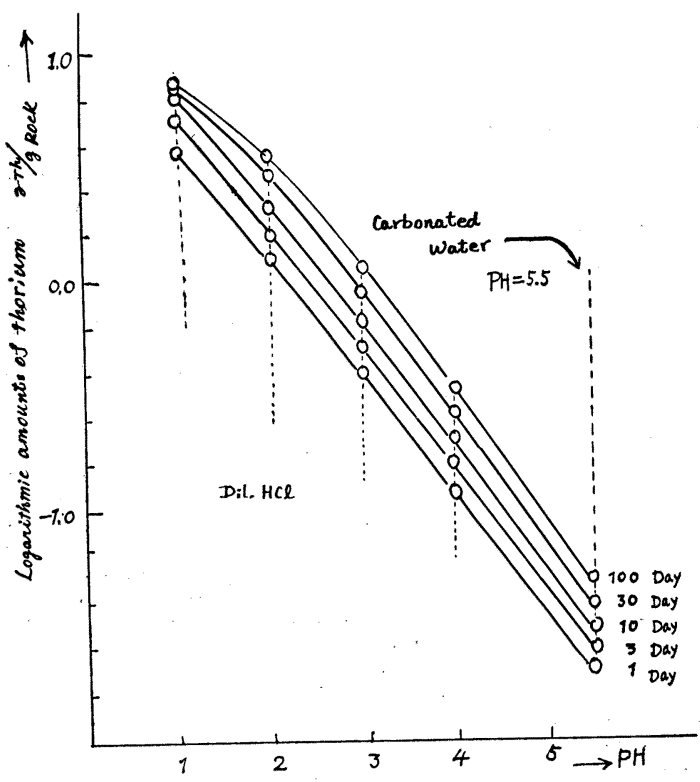

Fig. 3. The amounts of extraction of thorium from granite with dilute hydrochloric acid and carbonated water. (Temp. 18$23^{\circ} \mathrm{C}$ )

関係が成立つている．即ち，一定時間溶出処理を 行つた結果花崗岩から溶出されるトリウム量は, その時使用した溶出液の水素イオン濃度と密接な 関係にあると云ふことは，誠に注目すべき現象と 云兄よ5。

第 4 図は花崗岩粉末から溶出されたトリウム量 と, 溶出時間（日）の対数との関係を図示したも のである，これにみられるよ5に，溶出液の水素 イオン濃度が大きくなるに従つて，速にトリウム が溶出されて来ている。 又, 溶出されたトリウム

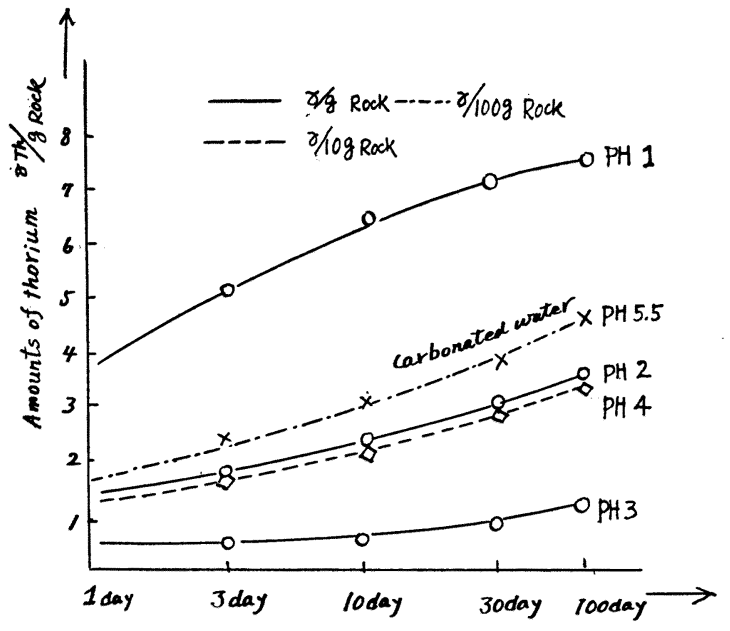

Fig. 4. The rate of extraction of thorium from granites.

量と溶出処理時間の対数との間に, 近似的な直線 関係が認められる.このような反応速度形式は, G. TAMMAN ${ }^{8)}$ 等によつて与えられた，新鮮な金 属亜鉛表面が腐蝕をうける際の反応速度形式を予 想させるものがある。

炭酸水処理による溶出結果は興味深いものがあ る. 即ち, 岩石のうける風化過程に於て, 雨水の 占る役割は複雑且重要なものであることは論をま たないのであるが，特に本実験の主目的である， 雨水による花崗岩中のトリウムの溶出問題を解明 する上に於て，ここに行つた炭酸水処理による花 崗岩中のトリウムの溶出挙動は重視すべきものと 考えられる. 何故ならば, 雨水は通常その中に 0.4 $0.5 \mathrm{cc} / l$ 程度の炭酸ガスを溶解していて, その結 果雨水は通常炭酸水の示す $\mathrm{pH}$ 值 5.5 附近の值を 示している（三宅9）の観測によれば，時として硫 酸根を含む $\mathrm{pH} 4$ 附近の降雨が存在する例がある が，ここでは例外とする).

さて，炭酸水によつて溶出したトリウム量は, 第 1 表に示されるように, 24時間処理で花崗岩粉 末 $1 \mathrm{~g}$ あたり $0.016 \gamma$ の值を示している. 従つ て雨水が炭酸水として新鮮な花崗岩面に作用する とすれば，花崗岩中に不安定な結合状態で存在し ているトリウムは充分溶出され得ると推定出来 る. 
c）花崗岩中のトリウムの雨水による機械的流 出に就て

前章で, 新鮮な花崗岩の炭酸水処理による実験 結果から, 花崗岩中に化学的に不安定な結合状態 で存在するトリウムは，雨水によつて溶出され得 ると推定した。しかし自然界では新鮮な花崗岩が 露頭している所は極めてまれであり，一般に表層 は風化をうけ変質していて，雨水はこの表層を洗 つているのが現状である. 従つて，この風化をう 変質した花崗岩からも，雨水によつてトリウム が溶出してくるものかどうかを検討しなければな らない。これに対して次のような実験を行つた。

京都市左京区瓜生山に花崗岩の石切場があり, ここで新鮮な花崗岩から風化をうけ変質した花崗 岩に至る, 種々風化様相の異る試料が採取出来 る.

さて花崗岩の造岩鉣物中最も風化をうけにくい のは石英で，長石がこれに次ぎ，雲母が最も風化 をうけ易いとされている．須藤 ${ }^{10)}$ の報告によれ ば，黒雲母を炭酸水中で一ヶ年間浸漬しておいた 結果, 次第に白色の粘土鉱物に変質した例がこれ を証明している. 事実, 瓜生山で採取される試料 にもこのよ5な現象がみられ，黒雲母に相当する 部分が黒褐色の酸化鉄様の物質で覆はれている試 料や，黒雲母が変質して白色鱗片状の䟝離し易い 形態を呈している試料, 更には雲母, 長石共に風 化変質して石英だけが残留しているもの等, 種々 の風化様相を示す試料が得られる.

この各種風化様相の異る試料について，その中 に含まれている全トリウム量, 6 規定塩酸処理で 溶出するトリウム量, $\mathrm{pH}=1$ の希塩酸 24 時間処 理で溶出するトリウム量, 及び炭酸水一週間処理 で溶出するトリウム量を夫々測定した，その結果 を第 2 表に示す.

第 2 表中, 風化試料 $\mathrm{A}$ とは黒雲母部が黒褐色酸 化鉄様に変質せるもの, 試料は B 黒雲母部が白色 鱗片状に変質し長石の变質も認められるもの, 試 料 $\mathrm{C}$ は表層近くに存在して, 石英を残して他は粘 土鉱物様に変質しているものである.

第 2 表にみられるように, 各試料中の全トリウ ム量及び 6 規定塩酸可溶のトリウム量は, 風化の
Table 2. The difference of thorium contents on fresh and weathered granites.

\begin{tabular}{|c|c|c|c|c|}
\hline$\gamma$ Th/g Rock & Fresh & $\begin{array}{l}\text { Weath- } \\
\text { ered A }\end{array}$ & $\begin{array}{l}\text { Weath- } \\
\text { ered B }\end{array}$ & $\begin{array}{l}\text { Weath- } \\
\text { ered C }\end{array}$ \\
\hline Total & 20.6 & 18.7 & 14.3 & 8.6 \\
\hline $\begin{array}{l}\text { 6N HCl Ext. } \\
\frac{6 \mathrm{~N} \mathrm{HCl}}{\text { Total }}(\%)\end{array}$ & $\begin{array}{r}7.8 \\
(36.9)\end{array}$ & $\begin{array}{c}6.4 \\
(34.2)\end{array}$ & $\begin{array}{c}3.1 \\
(23.1)\end{array}$ & $\begin{array}{r}1.2 \\
(13.8)\end{array}$ \\
\hline $\begin{array}{l}\mathrm{pH}=1 \mathrm{HCl} \text { Ext. } \\
\frac{\mathrm{pH}=1 \mathrm{HCl}}{\text { Total }}(\%)\end{array}$ & $\begin{array}{r}3.8 \\
(16.9)\end{array}$ & $\begin{array}{c}1.2 \\
(6.42)\end{array}$ & $\begin{array}{r}0.58 \\
(4.33)\end{array}$ & $\begin{array}{l}0.06 \\
(0.81)\end{array}$ \\
\hline $\begin{array}{l}\text { Carbonated } \\
\text { water Ext. } \\
\text { Carbonated } \\
\frac{\text { water }}{\text { Total }}(\%)\end{array}$ & $(0.12)$ & 0.000 & 0.000 & 0.000 \\
\hline
\end{tabular}

進んだ試料ほどその値が少くなつている。この結 果はW.L. SMITH ${ }^{11)}$ 等の $\beta$ 線放射能測定法によ つて, 新鮮な花崗岩と風化した花崗岩中の放射性 元素含有量の差を統計的に比較して, 放射性元素 は風化した花崗岩中には少く, 且つ風化過程に於 て放射性元素は母岩から失はれて行く傾向にある との報告と一致している.

希塩酸及び炭酸水処理によつて得られた結果は 興味深いものがある. 即ち, 該処理によつて溶出 されたトリウム量の，全トリウム含有量に対する 割合は，風化変質の著しい試料ほど小くなつてい るのが認められる．このことは，風化した花崗岩 中には新鮮花崗岩よりも可溶性のトリウムが少く 含まれていると云ふこと以外に，可溶性のトリウ ムは風化が進むに従つて次第に”希酸乃至炭酸水に 溶けにくい形に変化して行くのではないかと考え さるを得ない現象である、この現象は，風化を5 けた花崗岩と新鮮な花崗岩とがトリウムの溶出に 関して示す著しい相違点であり，従つて雨水が風 化した花崗岩層を流れる際には，溶出して来るト リウム量は極めて僅かなものと考兄らる．然る に一方, 河水中のトリウム含有量として得られて いる $0.05 \gamma / l^{12)}$ なる值は，第2表と比較してかな り高い值である．従つて，トリウムが河へ運ばれ るもら一つの経路, 即ち前者を化学的溶出経路と 仮称すればこれは機械的な流出経路なるものが考 えられる。 
本実験に使用した風化花崗岩にみられる黒雲母 の変質した，黒褐色酸化鉄様物質は，極めて脆弱 で，流水により容易に母岩から流し出され得る状 態を呈している. この黒雲母変質物を取出し, そ の中に含まれている 6 規定塩酸可溶のトリウム量 を測定して, 平均 $29.6 \gamma / \mathrm{g}$ の值を得た。この值 は母岩中の 6 規定塩酸可溶のトリウム量 $6.4 \gamma / \mathrm{g}$ の值の約 4 倍強の值である(トリウム及び他の放 射性元素は黒雲母に濃縮されて存在する傾向を持 つ. ${ }^{13)}$ 従つて, 比較的多量のトリウムを含む黒雲 母が最も風化变質し易く，且つ変質した結果脆弱 となり，雨水によつて容易に母岩から流し出され 得る状態にあることは, 花崗岩からトリウムが失 はれる原因の一つと考兄られる，更に注目したい 事は, 花崗岩は玄武岩等とくらべて, 風化をうけ ると脆くなり容易に崩潰する性質を持つことであ る. 従つて更に容易に前述の黒雲母の風化変成物 が雨水等により流出し易くなり, 又結晶間吵に存 在する leachable material も結晶崩潰に伴い風 雨にさらされ易い場所に現れ，母岩から流出して 河へ運ばれると考えられることである.

島 ${ }^{14)}$ はのような現象に関して興味深い.報告を 行つている. 即ち, 花崗岩地帯から流出して来た 土堷が地形の関係である場所に留積することがあ るが，この留積物中の放射性元素は母岩の花崗岩 中の放射性元素の量より多いと云らことである.

この報告は，本章で下した推定の妥当性を証明す るものと考えられる.

次に温泉水中のトリウムに関して附記したい。 本邦に多数の温泉が湧出しているが，その中含ト リウム温泉と云はれるものは共に花崗岩を基盤と する地带から涌出し, 泉質は含食塩炭酸泉乃至酸 性明ばん緑ばん泉に属するのを特徴としている. この間の事情と, 本報で行つた実験結果と併せ考 察するに，花崗岩が河水中にトリウムを放出する 主な資源となつていることは確実と考えられる。

\section{3. 結 論}

岩石中のトリウムが如何なる経路を経て河水に 移り海洋に運ばれるに至るかを解明する目的で, 花崗岩中に含まれる所謂可溶性形のトリウムに対
し，希酸及び炭酸水処理を行つて期待量のトリウ ムが溶出することを認めた．続いて風化変質した 花崗岩については同様溶出実験を行つた結果, 溶出されるトリウムは新蘚な花南岩より著るしく 少量なることを認め, 自然界に於て, 花崗岩中の トリウムが河や海へ搬出される他の経路として, 花崗岩造岩鉱物中, 比較的多量のトリウムを含 み，且つ風化をうけることにより脆弱となる黒雲 母が, 花崗岩の風化過程に於て崩潰し, 雨水等に より河へ流し出される可能性を検討した.

終に臨み，終始御指導御鞭鞋いただいた恩師石 橋雅義教授に深く感謝致します.

(昭和 32 年 10 月 分析化学年会講演 於京都)

\section{文献}

1) RANKAMA, K., 1946: “On the geochemical differenciation in the earths crust." Bull. Comn. Géol. Finlande, 173, 1-21.

2) Vernadsky, W., 1924: “La Géochimie" P. 363 Alcan Paris.

3) Tilton, G.R., C.C. PAtTerson, H. BROWN, R. INGHRAM, D.H. HAYDON, and E.S. LARSENJR., 1954 :

"The isotopic composition and distribution of lead, uranium and thorium in a Pre-Cambrian granite." United State Atomic Energy Comn. AECU-2840 June 25, 1400.

4) BROWN, H., W.J. BLAKE, A.A ChODOS, R. KOWALKOWSKI, C.R. MCKIMMY, G.J. NEUERBERG, L.T. SILVER, and A. UChIYAMA, 1953 : "Leaching studies of interstitial material in igneous rocks," Bull. Geol. Soc. Amer., 64, 1400.

5) Piccitto, E.E., 1950:

"Distribution de la radioactivite dans les roches eruptives." Bull de le Soc. belege de Geol. de Palentol. et d'Hydrol, 59, 170 -199 .

6）石橋雅義，東慎之介，1955:

“トリウムの微量分析法続報分析化学, 4, 14.

7）石橋雅義, 東慎之介, 1956:

“トリウムの微量分析法第 3 報分析化学, 5, 135,

8) TAMMAN, G. and W. KOSTER, 1922:

“ Die Bedeckungstheorie des Passivität der Metalle und ihre experimeutalle Begründung." $Z$. anorg. allgem. chem. 123, 196 (1922).

9) 二宅泰雄, 1934 :

“雨水の化学” 気象集誌 $\mathbf{1 7}, 31$. 
10) 須藤俊雄, 1950 :

“粘土鉱物” 岩波全書 p. 155.

11) SMiTh, W.L. and F.J. FlANAGAN, 1956:

" Use of the statistical methods to detect radioactive change due to weathering of a granite." Am. J. Sci., 254, 316.

12) ISHIBASHI, M, and S. HIGASHI, 1957:

" Estimation of microgram amount of thorium

in the Lake Biwa water." Bull. Inst. Chem. Res. Kyoto to Univ., 35, 7.

13) LARSEN, E.S. and PHAIR, G. 1955 :

“Nuclear geology" JOHN WILLY \& SONS New York.

14)島 誠, 1955 :

“地球化学探鉱法” p. 217. 丸善書店 